\title{
The Need for Integrating Entrepreneurial Education and Training in Nigerian Technical Colleges
}

\author{
Abubakar Ibrahim Muhammad, Yusri Bin Kamin, Nur Husna Binti Abd. Wahid
}

\begin{abstract}
Entrepreneurship education and training is systematic and recognize field of study that serves a catalyst for sustainable development, economic growth and social well-being of the society. In Nigeria technical colleges are designed to address the issue of job creation, youth employment, self-reliance, skill development and increase productivity so as to compete with the current opportunities and challenges in the labor market and the movement towards 4.0 IR for integrity. Unfortunately most of the college graduates lack the required entrepreneurial competencies and mindset to become successful entrepreneurs. Therefore to achieve such objectives there is an urgent need for integrating EET in the curriculum and the full implementation of the program in our technical colleges. The paper explores the need for integrating EET into the college curriculum; semi-structured interview was conducted with 12 selected Nigerian students in Universiti Teknologi Malaysia. The participants are from different geo-political zones of Nigeria, they are also from various faculties of the university; faculty of education, faculty of computing, faculty of management, faculty of science and faculty of electrical engineering. Purposive sampling technique was employed for the selection of the participants. 100 percent of the respondents' are in support of integrating EET into technical college curriculum and the full implementation of the program across the county. It is therefore recommended that National Board for Technical Education and policy makers should endeavor to address this issue as urgent because it will help Nigeria to prosper and the African continent in general.
\end{abstract}

Index Terms: Integrating, Entrepreneurial Education, Technical College.

\section{INTRODUCTION}

Entrepreneurial education and training (EET) is an organized formal education training design to prepare individuals to become responsible and enterprising persons through developing an entrepreneurial mindset and competencies attain the goals they set out for themselves (European Commission [EC], 2017). Interestingly there is a growing concern all over the world about entrepreneurship because entrepreneurship could serve as catalyst for achieving the objectives of economic growth and social development. Presently, EET is identified as an established field of study, growing in parallel with the interest of policymakers and students (Valerio, Parton, \& Robb, 2014). Since EET become a recognized field of study and a catalyst

Revised Manuscript Received on October15, 2019.

Abubakar Ibrahim Muhammad, Federal College of Education (Technical), Bichi Kano Nigeria. i.muhammad@graduate.utm.my

Yusri Bin Kamin, Technical and Engineering Education Department, Universiti Teknologi Malaysia, Johor, Malaysia.

Nur Husna Binti Abd. Wahid, Technical and Engineering Education Department, Universiti Teknologi Malaysia, Johor, Malaysia. for sustainable development it is obviously serve as a cross-link in most fields of studies TVET included. It has been stated (EC, 2017) people with entrepreneurial training are more employed than those without. Iacobuta \& Socoliuc, (2014); Sam \& van der Sijde, ((2014) opined that entrepreneur development is perceived as a main solution for job creation and sustainable economic growth. They further argued that as a result of these agitations, several calls and initiatives have been made to make entrepreneurship the growth engine of European economy and to set the principles of "think small first" at the core of national and European policies. Since early 1980 s there is a frequent deliberations on entrepreneurship and emphases are placed on entrepreneurship as one of the key driving factors of economic growth of Europe and the world in general (Dvoulety, 2017). Scholars are deliberating on entrepreneurship under various headings and sub-headings such as entrepreneurship orientation and its measurement in various types and groups of enterprise (Codogni, Duda \& Kusa, 2017). Likewise in Asia studies are going on about entrepreneurship development and economic growth of the countries. (Maclean, Jagannathan, Saivi, Power, Maclean, Pavlova, ... Chow, 2013) reported that the Asia and Pacific countries are growing prominently at the time; many countries are experiencing a period of great economic growth and development. This is due to the eminent growing of Asian economies and cooperation, together with globalization and technological innovation leading to long term changes in trade, business and labour markets. Promotion of entrepreneurship will contribute to additional increase the number of small and medium enterprises (SMEs) (Gosevska, Popovski \& Markoski, 2013).

Organizations such as Africa Development Bank, UNESCO and World Bank have commissioned various studies aim at identifying and investigating provisions for the incorporation of entrepreneurship training in technical institutions. Kabongo, (2008) reported shortest of studies that have tackled the issue of entrepreneurship education at the level of business degrees and programs offered at colleges and universities. He further argued that most of the context of entrepreneurship research in Sub Sahara Africa has focused on general principles, theoretical mechanisms of starting up entrepreneurial/entrepreneurs, and the implication of entrepreneurial success or failure at the macroeconomic level. In recent years, many of SSA countries established

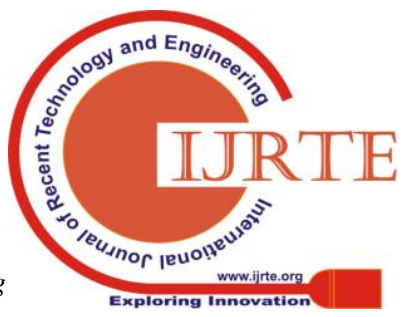


poverty reduction strategies specifically emphases promotion of small scale enterprises (SMEs) as a major way to reduce poverty particularly among the urban people. (Valerio et al., 2014) maintained that entrepreneurship is a solution to global and economic critical issues; hence EET would be an interesting intervention that stimulates students' decision to become a successful entrepreneur.

\section{A. The Need For Integrating EET In Technical Colleges}

Going by the above discussion it is evident that there is a need for integrating EET in our technical colleges in Nigeria. In Nigeria technical colleges are designed to address the issue of job creation, youth employment, self-reliance, poverty eradication, skill development and increase productivity so as to compete with the current opportunities and challenges in the labour market. These colleges are considered as the main vocational institution.

But most of the students of this institution are graduating without the required skills and competencies as observed by Dawha \& Medugu, (2016). In other hand, lack of integration between the curriculum taught in the colleges and the required skills in the workplace in small business and enterprise (Chekole, 2014) is a major obstacle to the growth and development of SMEs. With regards to this Enombo, Hassan \& Iwu, (2015); Syed, (2013) suggested the need for new school curriculum that would adopt the teaching of entrepreneurial education, this will serve as a solution to the current issues of unemployment and high poverty rate.

According to Ghina, Simatupang, \& Gustomo, (2014) the intention of instilling entrepreneurial mindset into students as well as producing new educated entrepreneurs and new businesses is to produce well-educated entrepreneurs who can create jobs. (Jabeen, Faisal, \& I. Katsioloudes, 2017) observed based on their study, the need for encouragement both from the government and the business community to invest heavily in EET more especially at the early age. They also reiterated that the investment should have long term positive effect on economic growth and global competitiveness by instilling entrepreneurial mindset among our teaming youth.

In view of this Ishiguro (2015) conducted a study on the Japanese high school students and found that to influence students entrepreneurial mindset there should be an ability to create ideas and convert them into action is one of the vital role of EET. (Ndudi \& Samuel, 2016) asserted that entrepreneurial competences obtained through formal education are considered among the most vital factors that influenced individual entrepreneurial ability. Based on this Syed, (2013) advocates the need for integrating entrepreneurship education as a subject in the curricula of all institutions of learning in Malaysia and other developing countries.

\section{PURPOSE OF THE STUDY}

The purpose of this study is to explore the need for integrating Entrepreneurship Education and Training into the curriculum of Nigerian Technical Colleges.

\section{A. Research Questions}

1) How do you explain entrepreneurship education?

2) What is your perception about the need for integrating
Entrepreneurship Education and Training in Nigerian Technical Colleges?

\section{RESEARCH METHODOLOGY}

The study was conducted using qualitative method to explore the need for integrating entrepreneurship training in technical colleges which utilized interview with participants. The data for the study were collected using semi-structured interview. Semi-structured was used because it gives participant the opportunity to express their views clearly in relation to the topic under study. Content analysis technique(Merriam, 2009) was used by the researcher to analyse the data collected from the interviews which were audio recorded. The semi-structured interview was conducted with 12 selected Nigerian students in UTM. The participants are from different geo-political zones of Nigeria, they are also from various faculties of the university such as faculty of education, faculty of computing, faculty of management, faculty of science and faculty of electrical engineering. Purposive sampling technique was employed for the selection of the participants. In purpose sampling the researcher (Bernard, 2002) has a free hand to select the participants based on their possessed qualities, thus no need for underlying theories or a particular number of participants.

The interview was guided by the research objective and consists of two parts: part A about the participant's background and part B was the interview protocol about the entrepreneurship education and training and the need for integrating EET in Nigerian technical colleges. After the collection of the result, transcription and analysing of the result inductively (Schreiber, 2008) was followed.

\section{FINDINGS AND DISCUSSIONS}

The analysis was done was based on the responses of the participants according to the identified key issues in the study. The views of the Nigerian students were recorded during the interview session under the key issues emerged in the interviews considering integrating entrepreneurship education training into Nigeria technical colleges curriculum The general characteristic of the participants was similar in term of education, hence their responses were appeared to be similar but with little discrepancies. Therefore the main findings of the study were summarized that Nigerian students' have a good perception about entrepreneurial education, all of the participants are in the view of the need for integration of entrepreneurial education and training into the Nigeria technical colleges curriculum.

The first question was about the definition of entrepreneurial education and training, the respondents were asked to explaining what they understand with entrepreneurial education and training. The following are the some of their responses:

"To my own understanding entrepreneurship education can be simply a way that we can incorporate new skill in that particular field of study in such away 
whoever brought up from the system can be able to develop and design a kind of skill using his own talent and education he acquired from the field so that he can

"Entrepreneurship in my own perspective is act of acquiring a particular skill in marketing in today society"

"Entrepreneurship is simply a strategy of providing awareness and skills as supplementary qualities instill in the students' learning processes in the school. Students are taught on how to efficiently utilize the opportunities available in their society by either innovation or emulation of best practices that promote social welfare and development."

The responses continue as follow: individual acquires or learns through formal way that can use for self-reliance and provide employment for other people."

"Entrepreneurship education is a teaching and learning process of management and leadership style that involve pursuing opportunities without regard to resources currently controlled. It is any attempt at new business or new venture creation such as self-employment, a new organization, or a team or an established business."

In summary the participants have clearly shown that they are familiar with entrepreneurial education and training. Having established their knowledge of the issue at stack, the participants were then asked to express their perception about the need to integrate this type of education into the curriculum of technical colleges in Nigeria. Some of the responses are:

"While actually ...eh in a my own perspective, there is quite alright need for that entrepreneurship education, why because even though people understand it in different perspective, but from my own perspective we shouldn't consider technical education is enough, it means some of the scholars do understand that the entrepreneurship sorry technical education we are given to the students itself is an entrepreneurship but we shouldn't understand it and narrow it in that perspective"

"Yeah is obvious integrating entrepreneurship in technical colleges is of a great paramount."

"Yeah, actually, in Nigeria we have a long way to go in regards to entrepreneurship education because if you look at developed countries like the Europe and US they have made policy such that the entrepreneurship education have being eh ... inculcated into their curriculum because they believe in the way of development of their economic growth, and look at Nigeria today laymen joblessness is as a result of the lack of this entrepreneurship education."

Examining the responses 100 percent of the participants has indicated a clear support of integrating entrepreneurial education and training in technical colleges' curriculum in Nigeria. Their responses were coded as "I support it integration in technical colleges". This finding is in line with sustain himself it can save as career to him."

"Entrepreneurship education is an education which

(Marques, Ferreira, Gomes, \& Gouveia Rodrigues, 2012), (Ananda \& Mukhadis, 2016)(Cheraghi \& Schøtt, 2015). in the same vein(Camacho, Janowski, Konak, \& Kulturel-Konak, 2016) college students are facing difficulties after graduation such as poverty and unemployment, to overcome these challenges it requires technological and social innovations that are championed by new breeds of entrepreneurs. The finding is also in line with Buli \& Yesuf, (2015)observed that there is a need for changes in educational practice curriculum to include entrepreneurial education and training.

As a result of above mentioned reasons is suffice for integrating and implementing entrepreneurial education and training in our technical colleges for sustainable development, economic growth, job creation that would trigger the move towards 4.0 IR for integrity and social development. However, Buli \& Yesuf, (2015) opined that the lingering problems that embedded the growth and development of developing countries could resolved through vocational and technical education by integrating EET as a device to promote economic and social progress. To this end Cubico et al., (2013) believed that entrepreneurial human capital and national growth are bond together while entrepreneurial competences are important for scholarly research. UNCTAD (2015) described the vital role of micro, small and medium enterprises as the key drivers of job creation, providing two-thirds of all formal jobs in developing countries in Africa, Asia and Latin America and 80 per cent of all formal jobs in low-income countries in sub-Saharan Africa.

\section{CONCLUSION}

The study is a preliminary which focus on the need assessment for the integration and implementation of EET in technical colleges. Looking at the scope and the nature of the respondents the findings are worth of generalization. Therefore this study gives away for further intensive research in entrepreneurship and technical education in Nigeria.

\section{Recommendations}

1) To achieve the stated goals in the national policy of education there is an urgent need for integrating EET in the curriculum and full implementation of the program in our technical colleges.

2) National Board for Technical Education and the policy makers should endeavour to address this issue as urgent because it will help Nigeria to prosper and the African continent in general.

\section{REFERENCES}

1. Ananda, A. F., \& Mukhadis, A. (2016). Production unit as edupreneurship, cooperation business and industrial world with the school for the development of vocational student entrepreneurship mindset. In the International Mechanical Engineering and Engineering Education Conferences (IMEEEC) (Vol. 1778, pp. 1-10). American Institute of Physics (AIP) Publishing. https://doi.org/10.1063/1.4965782 
2. Buli, B. M. \& Yesuf, W. M. (2015). Determinants of entrepreneurial intentions: Technical-vocational education and training. Education + Training, 57(8/9), 891-907. https://doi.org/10.1108/ET-10-2014-0129

3. Camacho, A. P., Janowski, A., Konak, A., \& Kulturel-Konak, S. (2016). Creative problem solving builds entrepreneurial mindset. ISEC 2016 Proceedings of the 6th IEEE Integrated STEM Education Conference, 65-70. https://doi.org/10.1109/ISECon.2016.7457556

4. Chekole, Z. G. (2014). Challenges and prospects of micro and small enterprises in Awi zone: The case of Dangila district. Indra Gandhi National Open University. Retrieved from http//www.googlescholar.com

5. Cheraghi, M., \& Schøtt, T. (2015). Education and training benefiting a career as entrepreneur. International Journal of Gender and Entrepreneurship, $7(3)$, https://doi.org/10.1108/IJGE-03-2013-0027

6. Codogni, M., Duda, J. \& Kusa, R. (2017). Entrepreneurial orientation in high-tech and low-tech SMEs in Malopolska region, 18(1), 7-22. Retrieved from http://dx.doi.org/10.7494/manage.

7. Cubico, S., Formicuzzi, M., Ardolino, P., Noventa, S., Ferrari, A., Sartori, R., \& Favretto, G. (2013). Entrepreneurial human capital: A model for analyzing and validating the key competences for entrepreneurship. Research in Entrepreneurship and Small Business, RENT(XXVII), $1-19 . \quad$ Retrieved from https://www.researchgate.net/requests/r38332643?pli=1\&loginT=0coj Da6GvZN5ACKPsnKIxGmEYJLympab_4EggACF4OqAzqujycC2eG Z2tI_ON9oPq0Zn6jK-JHM5VE4iaNi8jvHL\&uid=LZZY1K11 mlZ7mv uWt8amXnGQxW6e86sLxyVZ\&cp=re386_x_p1\&ch=reg\&utm_medi um=email\&utm_source=researchgate\&ut

8. Dawha, J. M. \& Medugu, J. D. (2016). Emerging entrepreneurial and business planning competencies required by motor vehicle mechanic students in establishing entreprise in Bauchi and Gombe states, Nigeria. International Journal of Humanities Social Sciences and Education (IJHSSE), 3(1), 156-161. Retrieved from htt//www.googlescholar.com

9. Dvoulety, O. (2017). What is the Relationship between Entrepreneurship and Unemployment in Visegrad Countries? Central European Business Review, 6(2), 42-53.

10. Enombo, J. P., Hassan, S. L. \& Iwu, C. G. (2015). The significance of entrepreneurship education in Gabonese schools: justifications for a new curriculum design. Socioeconomica - The Scientific Journal for Theory and Practice of Socio-Economic Development, 4(8), 493-506. https://doi.org/dx.doi.org/10.12803/SJSECO.48139 JEL:

11. European Commission. (2017). European commission. Retrieved November 19, 2017, from https://ec.europa.eu/jrc/en/publication/eur-scientific-and-technical-rese arch-reports/entrecomp-entrepreneurship-competence-framework

12. Ghina, A., Simatupang, T. M., \& Gustomo, A. (2014). A systematic framework for entrepreneurship education within a university context. International Education $\quad$ Studies, 7(12), 1-19. https://doi.org/10.5539/ies.v7n12p1

13. Gosevska, L. , Popovski, V. \& Markoski, G. (2013). The role and influence of entrepreneurship on the growth and expanding of small and medium enterprises in the Republic of Macedonia. Iliria International Review, 3(1), 89-102. https://doi.org/10.21113/iir.v3i1.100

14. Iacobuta, A-O. \& Socoliuc, O.-R. (2014). European entrepreneurship in times of crisis : realities, challenges and perspectives (No. L26; M13; Y1) (Vol. VI). Alexandru. Retrieved from www.google.com

15. Ishiguro, J. (2015). What influences entrepreneurial career choice?: An exploratory analysis of the Sally Caird 's GET2 for Japanese high school students. Academy of Entrepreneurship Journal, 21(1), 44-58. Retrieved

from http://connection.ebscohost.com/c/articles/108588438/what-influencesentrepreneurial-career-choice-exploratory-analysis-sally-cairds-get2-ja panese-high-school-students

16. Jabeen, F., Faisal, M. N., \& I. Katsioloudes, M. (2017). Entrepreneurial mindset and the role of universities as strategic drivers of entrepreneurship. Journal of Small Business and Enterprise Development, 24(1), 136-157. https://doi.org/10.1108/JSBED-07-2016-0117

17. Kabongo, J. D. (2008). The Status of entrepreneurship education in colleges and universitis in Sub-Saharan Africa. Retrieved from https://www.researchgate.net/profile/Jean_Kabongo2/publication/2284 66849_The_status_of_entrepreneurship_education_in_colleges_and_u niversities_in_sub-Saharan_Africa/links/00b7d537e5f985c32f000000. pdf

18. Maclean, R., Jagannathan, S., Saivi, J., Power, C. N., Maclean, R.,
Pavlova, M., ... Chow, J. K. F. et al. (2013). Technical and Vocational Education and Training: Issues, Concerns and Prospects Vol. 19. (J. Maclean, R., Jagannathan, S. \& Sarvi, Ed.), Asian Development Bank. New York, London: Springer Dordrecht Heidelberg. https://doi.org/10.1007/978-94-007-5937-4

19. Marques, C. S., Ferreira, J. J., Gomes, D. N., \& Gouveia Rodrigues, R (2012). Entrepreneurship education: How psychological, demographic and behavioural factors predict the entrepreneurial intention. Education $+\quad$ Training, 54(8/9), 657-672. https://doi.org/10.1108/00400911211274819

20. Ndudi, O. C. \& Samuel, V. S. (2016). Technical vocational education and training and local technologies: A panacea for sustainable entrepreneurship skills development. Pearl Research Journals, 2(3), 32-36.

21. Sam, C. \& van der Sijde, P. (2014). Understanding the concept of the entrepreneurial university from the perspective of higher education models. Higher Education, 68(6), 891-908. https://doi.org/10.1007/s10734-014-9750-0

22. Schreiber, J. B. (2008). The Sage Encyclopedia of Qualitative Research Methods. In L. M. Given (Ed.), SAGE (p. 1043). Los Angeles: Sage publications, Inc. https://doi.org/10.4135/9781412963909

23. Syed, Z. A. (2013). The need for inclusion of entrepreneurship education in Malaysia lower and higher learning institutions. Int Entrep Manag J, 55(2), 191-203. https://doi.org/10.1007/s11365-016-0390-y

24. Valerio, A., Parton, B., \& Robb, A. (2014). Entrepreneurship education and training programs around the world. World Bank Publications. https://doi.org/10.1596/978-1-4648-0202-7

\section{AUTHORS PROFILE}

First Author: Abubakar Ibrahim Muhammad, Federal College of Education (Technical), Bichi Kano Nigeria. i.muhammad@graduate.utm.my

Second Author: Yusri Bin Kamin, Technical and Engineering Education Department, Universiti Teknologi Malaysia, Johor, Malaysia.

Third Author: Nur Husna Binti Abd. Wahid, Technical and Engineering Education Department, Universiti Teknologi Malaysia, Johor, Malaysia. 